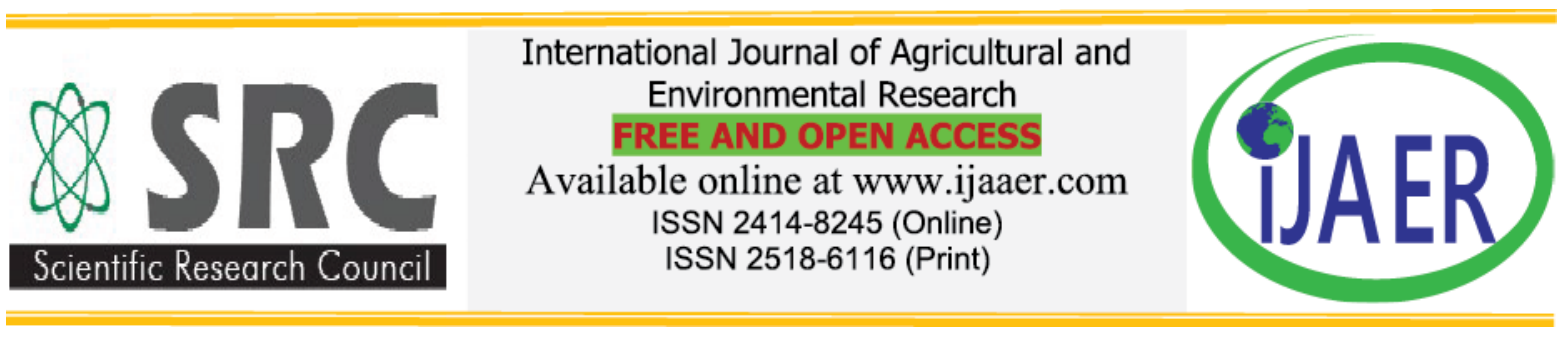

\title{
ASSESSMENT OF YIELD COMPONENTS AND THEIR ASSOCIATION IN F2 POPULATIONS OF WHEAT
}

\author{
Touheed Iqbal ${ }^{1}$, Ghulam Hassan ${ }^{2}$ and Iqbal Hussain ${ }^{2}$ \\ ${ }^{1}$ Agricultural Research Institute, Dera Ismail Khan, KP, Pakistan \\ ${ }^{2}$ Department of Plant Breeding \& Genetics, The University of Agriculture, Peshawar, Pakistan \\ Corresponding author E-mail: touhed.ik@gmail.com
}

\begin{abstract}
Keeping in view the role of wheat in Pakistan, among $F_{2}$ populations, maximum grain yield plant the current research was conducted to compute the ${ }^{l}$ was given by cross combinations Barsat / Siren extent of transmissibility and to derive information (27.93 g), AUP-5008 / Siren (26.09 g) and Tatara / on the correlation of grain yield with itsPS-05 $(25.65 \mathrm{~g})$. The assessments of heritability component traits. Sixteen $F_{2}$ populations of wheatand genetic advance manifested that $F_{2}$ and their eight parental lines were evaluated at thepopulations, Saleem-2K / Janbaz, Tatara / F.S, University of Agriculture, Peshawar-PakistanAUP-5008 / PS-05 and Tatara / PS-05 had highly during wheat season of 2013-14. Experiment washeritable characters along with high genetic conducted in randomized complete block designadvance, which offer an opportunity for earlier with three replicates. Analysis of varianceselection. Hence, more emphasis should be given manifested significant differences amongto these crosses in future wheat breeding genotypes for all the studied traits. Similarly,programs. Moreover, the perusal of correlation mean squares due to parents, $F_{2}$ populations andanalysis revealed that traits like days to maturity, parents vs. $F_{2}$ 's were also significant for all theflag leaf area, plant height, fertile tillers plant ${ }^{-1}$, traits under study except harvest index. On thebiological yield and harvest index appeared to be basis of mean performance, maximum grain yieldmost essential sources of affecting the final yield, plant $^{-1}$ among parents was given by Fakhr-e-suggesting that upsurge in wheat yield could be Sarhad $(27.16 \mathrm{~g})$ and PS-05 (26.06 g), whileadmissible by selecting these traits.
\end{abstract}

Key words: Correlation, genetic advance, heritability, $\mathrm{F}_{2}$ populations and wheat.

\section{INTRODUCTION}

Wheat is life and prince among cereals and plays promising role in the food and nutritional security of Pakistan. It is the most essential and major consumable food cereal in our country, therefore, it holds unique significance in the agricultural policies of the government. Wheat contributes $2.2 \%$ to GDP and about $10.3 \%$ to the total value added in agriculture. According to FBS (2015), the total wheat production in Pakistan was 25.24 million tons from 9039.0 thousand hectares with an average yield of $2987 \mathrm{Kg} \mathrm{ha}^{-1}$ in which Khyber Pakhtunkhwa contributes about 1140.6 thousand tons from 729.8 thousand hectares with an average yield of $1560 \mathrm{Kg} \mathrm{ha}{ }^{-1}$. Genetic variability in plants is the initial step in understanding how to improve or produce new plants with better yield potential, and its reduction makes the crops progressively vulnerable to diseases and adverse climatic changes/stresses (Aremu, 2012). Therefore, it is important to get satisfactory information on the extent and type of genetic variability and their corresponding heritability. In Pakistan, significant upsurge in wheat yield had mere achieved through conventional breeding methods like hybridization followed by isolation of desirable pure lines at the end. Among segregating generations, the second filial generation holds significant importance, where selection of desirable phenotypes has to be done more critically. Hence, to exercise more effective selection, a thorough knowledge on the extent of transmissibility of yield components is needed. According to Ijaz et al. (2013), the exploration of genetic variation in breeding material is of major interest to plant breeders and helpful in achieving higher return per unit area in any crop plant. Since there is direct relation between heritability and response to selection 
(genetic advance), therefore, higher estimates of heritability and genetic advance simplifies selection procedures for plant breeders (Shoukat $e t$ al., 2007). Rashid et al. (2013) estimated high heritability accompanied by high genetic advance for some polygenic traits in seven $\mathrm{F}_{2}$ populations of wheat. Similarly, Hussain et al. (2013) estimated higher percentage of heritability and genetic advance in different $F_{2}$ populations of wheat. Attempts have been made since 1966 to develop high yielding varieties with consistent performance. As yield is a complex character and is the product of multi-growth factors, therefore, initiating any wheat breeding program based on yield components requires the knowledge of association between the yield and its component traits. Gelalcha and Hanchinal (2013) found that tillers plant ${ }^{-1}$, spikes $\mathrm{m}^{-2}$, spike length and biomass yield showed significant contribution towards grain yield. Abderramane et al. (2013) pointed out that spikes plant ${ }^{-1}$, grains spike ${ }^{-1}$ and total biomass was positively correlated with grain yield. Similarly, Abd El-Mohsen et al. (2012) found notable contribution of spike length, spikelets and grains spike ${ }^{-1}$ and test weight at both phenotypic and genotypic levels towards grain yield in wheat. Association among yield components are therefore important because if the association between two traits is positive then one trait could be improved indirectly by improving the other trait. The present research study was therefore conducted to assess the extent on transmissibility and correlation coefficient among selected characters to screen out suitable $F_{2}$ populations of wheat for onward breeding program.

\section{MATERIALS AND METHODS}

Sixteen $F_{2}$ populations were evaluated along with their parents in randomized complete block design in three replications at the experimental field of Department of Plant Breeding and Genetics, The University of Agriculture, Peshawar-Pakistan during Rabi 2013-14. Each entry was planted in 4 rows with a row length of $3 \mathrm{~m}$ length with plant to plant and row to row distances of $15 \mathrm{~cm}$ and 30 $\mathrm{cm}$, respectively. All the biometrical observations were recorded on randomly selected 20 guarded plants from parents and $F_{2}$ populations respectively in each replication. The mean values recorded for yield and yield attributing traits viz., days to $50 \%$ heading and maturity, flag leaf area, plant height, fertile tillers plant ${ }^{-1}$, biological yield plant $^{-1}$, spike length, spikelets and grains spike ${ }^{-1}$, 100-grain weight, grain yield plant ${ }^{-1}$ and harvest index plant $^{-1}$ were used for statistical analysis following the analysis of variance technique as outlined for RCB design by Singh \& Chaudhary (1985). Broad-sense heritability $\left[h^{2}{ }_{(B . S)}\right]$ for each character was assessed using the formula described by Mahmud \& Kramer (1951) as: $h^{2}{ }_{(\mathrm{B} . S)}=\left[\mathrm{VF}_{2}-\right.$ $\sqrt{(V P 1) \times(V P 2)}] / \mathrm{VF}_{2}$, where $\mathrm{VF}_{2}=$ variance of Particular $\mathrm{F}_{2}$ population, $\mathrm{VP}_{1}=$ Variance of particular Parent 1 and $\mathrm{VP}_{2}=$ Variance of particular Parent 2. The magnitude of heritability was characterized as low $(0-30 \%)$, moderate $(>30$ $60 \%)$ and high $(<60 \%)$ according to Robinson et $a l .$, 1949. Expected genetic advance (GA) was computed according to Allard (1960) as: GA= $\sigma^{2} p \times \mathrm{k} \times h^{2}{ }_{(B S)}$, where $\sigma^{2} p=$ phenotypic standard deviation, $\mathrm{k}$ is standardized selection differential constant (1.40) at $20 \%$ selection intensity and $h^{2}$ $(B . S)=$ broad-sense heritability of particular trait in fraction. Phenotypic correlation was computed following the method of Al-Jibouri et al. (1951) as: Phenotypic correlation $(r p)=\frac{\operatorname{COV}_{P\left(x_{1} x_{2}\right)}}{\sqrt{\sigma^{2} P\left(x_{1}\right) \cdot \sigma^{2} P\left(x_{2}\right)}}$.

Where;

$\operatorname{COV}_{\mathrm{P}(\mathrm{x} 1 \times 2)}=$ Phenotypic covariance among traits $\mathrm{x}_{1}$ and $\mathrm{x}_{2}$

$$
\begin{aligned}
& \sigma_{p_{(\mathrm{x} 1)}}^{2}=\text { Phenotypic variance of trait } \mathrm{x}_{1} \\
& \sigma_{p(\mathrm{x} 2)}^{2}=\text { Phenotypic variance of trait } \mathrm{x}_{2}
\end{aligned}
$$

\section{RESULTS AND DISCUSSION}

\section{Genetic variability and Mean performance:}

Plants breeder's real aim and objective is to develop cultivars with high yield potential, better quality and consistent performance. Achievement of this goal depends on inbuilt genetic variability, in which desirable lines are to be selected for further exploitation, to achieve the target. Plant breeders are interested in short duration early maturing wheat genotypes. Minimal days to heading are preferred while breeding for early maturity. Similarly, Flag leaf area is also important character assessed by plant breeders, because it is directly associated with final yield (Rashid et al., 2013). It plays prominent role in determining yield potential of wheat because it accounts for about $70 \%$ of photoassimilates that go directly into seeds. Plant height in wheat is very important in terms of lodging resistance. In literature, it is reported that deal plant height in respect of fertilizer responsiveness and lodging resistance may range from 90-100 cm (Dogan, 2009). Fertile tillers plant ${ }^{-1}$, spike length and spikelets and grains spike $^{-1}$ are important production traits in wheat, and play significant role in grain yield plant ${ }^{-1}$. Maximum fertile tillering capacity and longer and healthier spikes with more spikelets and grains will obviously lead to higher return. The analyzed data manifested significant $(P \leq 0.01)$ differences among genotypes for all the studied traits, representing sufficient genetic variability for 
effective selection (Table 1). Mean squares due to parents, $\mathrm{F}_{2}$ populations and parents vs. $\mathrm{F}_{2}$ `s were also significant $(P \leq 0.05 \& 0.01)$ for all the studied traits except harvest index for parents vs. $\mathrm{F}_{2}$ `s. Studies on assessment of genetic variability in segregating populations of wheat has been conducted earlier (Saleem et al., 2016; Azam et al., 2013; Sial et al., 2013; Eid, 2009; Firouzain et al., 2003). The variability observed among genotypes for all the assessed traits was high, as reflected by its wide range from 122.00 to 133.33 days for heading, 22.79 to $36.43 \mathrm{~cm}^{2}$ for flag leaf area, 168.67 to 173.67 days for maturity, 90.71 to $108.97 \mathrm{~cm}$ for plant height, 7.40 to 10.23 for fertile tillers plant ${ }^{-1}, 37.87$ to $60.93 \mathrm{~g}$ biological yield plant $^{-1}, 10.96$ to $13.52 \mathrm{~cm}$ for spike length, 18.22 to 22.47 for spikelets spike ${ }^{-1}, 60.77$ to 78.88 for grains spike ${ }^{-1}, 3.64$ to $4.85 \mathrm{~g}$ for 100 -grain weight, 13.80 to $27.93 \mathrm{~g}$ for grain yield plant ${ }^{-1}$ and 36.23 to $47.87 \%$ for harvest index plant $^{-1}$ (Table 2). The earliest maturing parent was Siren which took 168.67 days to maturity, followed by Barsat (169.33 days). Maximum flag leaf area (34.43 $\left.\mathrm{cm}^{2}\right)$, plant height $(108.97 \mathrm{~cm})$ and 100-grain weight $(4.71 \mathrm{~g})$ was calculated for PS-05, respectively, while maximum values for flag leaf area $\left(23.74 \mathrm{~cm}^{2}\right)$, plant height $(90.71 \mathrm{~cm})$ and fertile tillers plant ${ }^{-1}$ (8.13) were observed for Saleem-2K, respectively. Maximum mean value for fertile tillers plant ${ }^{-1}$ (10.23) was observed for AUP-5008, while Barsat produced the longest spikes $(13.30 \mathrm{~cm})$ among parents. Janbaz shows superiority for biological yield plant $^{-1}$ (59.03 g) and spikelets spike ${ }^{-1}$ (21.97), while Fakhr-e-Sarhad was best in respect of grains spike ${ }^{-1}(74.10)$, grain yield plant ${ }^{-1}(27.16 \mathrm{~g})$ and harvest index $(47.87 \%)$. Similarly, among $\mathrm{F}_{2}$ populations, Tatara / Janbaz was the earliest in heading (122.00 days) and manifested maximum flag leaf area $\left(30.34 \mathrm{~cm}^{2}\right)$, while Saleem-2K / PS-05 was the earliest maturing (168.67 days) cross combination. Late heading (133.33) and maturity (173.67 days) was observed in Saleem-2K / Siren and Saleem-2K / FS and AUP-5008 / Janbaz, respectively. In respect of height, most of the $\mathrm{F}_{2}$ populations achieved considerable plant height. AUP-5008 / FS (9.92), AUP-5008 / Siren (9.77) and AUP-5008 / PS-05 (9.72) were high tillering cross combinations. The longest spikes $(13.52 \mathrm{~cm})$, maximum grain yield (27.93 g) and biological yield plant ${ }^{-1}$ (60.93 g) among all $\mathrm{F}_{2}$ populations was produced by Barsat / Siren. Tatara / Janbaz was the next best cross combination in respect of spike length $(13.18 \mathrm{~cm})$, while AUP-5008 / Siren (26.09 g) and Tatara / PS$05(25.65 \mathrm{~g})$ were the next high yielding cross combinations. Saleem-2K / Janbaz (22.47) and Basrat / PS-05 (78.88) produced utmost number of spikelets and grains spike $^{-1}$, respectively. Maximum hundred grain weight of $4.85 \mathrm{~g}$ was recorded for Tatara / PS-05, followed by Barsat / Siren (4.72 g), while maximum harvest index was recorded for AUP-5008 / Siren (45.47\%), followed by Barsat / Siren $(45.30 \%)$.

Table 1: Mean squares for various traits of 24 of wheat genotypes.

\begin{tabular}{|c|c|c|c|c|c|c|c|}
\hline $\begin{array}{ll}\begin{array}{l}\text { Source } \\
\text { variation }\end{array} & \text { of } \\
\end{array}$ & $\begin{array}{l}\operatorname{Rep} \\
(d f=2)\end{array}$ & $\begin{array}{l}\text { Genotypes } \\
(d f=23)\end{array}$ & $\begin{array}{l}\text { Parents (P) } \\
(d f=7)\end{array}$ & $\begin{array}{l}\text { F2 populations } \\
(d f=15)\end{array}$ & $\begin{array}{l}\text { P vs. F2's } \\
(d f=1)\end{array}$ & $\begin{array}{l}\text { Error } \\
(d f=46)\end{array}$ & $\begin{array}{l}\mathrm{CV} \\
(\%)\end{array}$ \\
\hline $\begin{array}{l}\text { Days to } 50 \% \\
\text { heading }\end{array}$ & 9.50 & $36.91 * *$ & $50.14 * *$ & $31.69 * *$ & $22.57 *$ & 4.08 & 1.57 \\
\hline Flag leaf area & 2.96 & $25.40 * *$ & $48.96^{* *}$ & $14.70 * *$ & $20.99 *$ & 4.29 & 7.49 \\
\hline $\begin{array}{ll}\begin{array}{l}\text { Days } \\
\text { maturity }\end{array} & \text { to }\end{array}$ & 1.93 & $9.71 * *$ & $9.05^{* *}$ & $9.27 * *$ & $21.01 * *$ & 2.84 & 0.98 \\
\hline Plant height & 23.79 & $69.46 * *$ & $91.22 * *$ & $58.99 * *$ & $74.21 * *$ & 10.67 & 3.27 \\
\hline $\begin{array}{ll}\text { Fertile } & \text { tillers } \\
\text { plant }^{-1} & \end{array}$ & 0.26 & $1.99 * *$ & $1.61 *$ & $1.83 * *$ & $7.07 * *$ & 0.66 & 9.07 \\
\hline $\begin{array}{l}\text { Biological } \\
\text { yield }\end{array}$ & 7.87 & $119.28 * *$ & $193.41 * *$ & $90.89 * *$ & $26.15^{*}$ & 5.31 & 4.58 \\
\hline Spike length & 0.50 & $1.39 * *$ & $1.65^{* *}$ & $1.18 * *$ & $2.65 *$ & 0.46 & 5.44 \\
\hline $\begin{array}{l}\text { Spikelets } \\
\text { spike }^{-1}\end{array}$ & 1.02 & $2.83 * *$ & $5.18 * *$ & $1.69 * *$ & $3.61 * *$ & 0.50 & 3.49 \\
\hline Grains spike $^{-1}$ & 2.60 & $64.21 * *$ & $74.39 * *$ & $61.93 * *$ & $27.08 * *$ & 2.58 & 2.36 \\
\hline $\begin{array}{l}\text { 100-grain } \\
\text { weight }\end{array}$ & 0.03 & $0.28 * *$ & $0.44 * *$ & $0.20 * *$ & $0.24 * *$ & 0.02 & 3.50 \\
\hline $\begin{array}{ll}\begin{array}{l}\text { Grain } \\
\text { plant }^{-1}\end{array} & \text { yield } \\
\end{array}$ & 1.55 & $37.68 * *$ & $66.56^{* *}$ & $25.86 * *$ & $12.86^{* *}$ & 1.40 & 5.48 \\
\hline Harvest index & 10.13 & $17.38 * *$ & $34.87 * *$ & $10.08 * *$ & 4.40 & 3.90 & 3.64 \\
\hline
\end{tabular}

$*, * *=$ Significant at $5 \%$ and $1 \%$ level of probability, respectively. 
Heritability and genetic advance: Heritability together with genetic advance (gain) provides approximate estimates of achievable gain at specific selection intensity. In this regard, Memon et al. (2005) reported that high heritability and genetic advance in wheat offer better opportunity for selecting better genotypes in early generations, because higher magnitude of heritability makes selection procedure more effective and simpler (Firouzain et al., 2003). Similarly, Khan et al. (2003) also suggested that higher magnitude of heritability and genetic advance simplifies the selection procedure. Hence, it is concluded that assessment of heritability along with genetic advance had significant role in deciding the strategy and suitability for selection of a character. The present study revealed that all the characters were highly heritable in most of the $\mathrm{F}_{2}$ crosses. Higher estimates of heritability $(>60 \%)$ and genetic advance for flag leaf area $(0.56-0.92$ and $\left.5.07-12.16 \mathrm{~cm}^{2}\right)$, plant height $(0.25-0.87$ and 2.06$15.59 \mathrm{~cm})$, fertile tillers $(0.27-0.84$ and $0.87-4.22$ tillers), biological yield (0.72-0.95 and 18.18$28.64 \mathrm{~g})$, spikelets spike ${ }^{-1}(0.45-0.83$ and $1.07-2.55$ spikelets), grains spike ${ }^{-1}(0.56-88$ and $4.76-14.83$ grains), grain yield (0.69-0.92 and 8.96-13.48 g) and harvest index $(0.48-0.82$ and $4.89-10.86 \%)$ in most of the $F_{2}$ crosses (Table 3) signifies the chance of success through efficient selection. These results also indicated high genetic potential for these traits, minimal environmental effects and presence of predominant role of additive genes; hence early generation selection based on these traits could be fruitful. Saleem et al. (2016) observed genetic variability and assessed high heritability and genetic advance for days to heading, plant height, flag leaf area and grain yield in most of the $F_{2}$ populations of wheat and suggested that these traits are under genetic control. Similarly, studies conducted on genetic variability and heritability by Ijaz et al. (2015), Waqas et al. (2014), Hussain et al. (2013), and Ajmal et al. (2009) also observed significant differences among $F_{2}$ populations and assessed high heritability accompanied by high genetic advance for the studied traits in most of the $F_{2}$ crosses. However, Ijaz and Samiullah (2013) observed moderate heritability estimates for spike length and flag leaf area and low for tillers plant ${ }^{-1}$ and grain yield in segregating populations of wheat. Characters like spike length $(0.32-0.61$ : 0.43-1.04 cm) and 100-grain weight (0.11-80: $0.07-0.85 \mathrm{~g})$ were low $(<30 \%)$ to moderately heritable $(>30 \%)$ and manifested low to moderate genetic advance in most of the segregating populations as reflected by its range. Such magnitude of heritability and genetic advance manifested that selection based on these characters should be practiced with care or should be delayed to later generations for improvement. These results are partially in line with the results reported earlier by Rashid et al. (2013), Karim and Jahan (2013) and Saleem et al. (2003).

Correlation analysis: Johnson et al. (1955) stated that two main reasons are believed for traits association; 1) pleiotropic gene effect which means that one gene influences two or more traits and 2) linkage effect which affect both traits simultaneously. Assessment of association between traits has significant importance in selecting best genetic stock for achieving maximum return per unit area in wheat. In this regard, correlations were assessed among various characters in order to identify desirable characters for indirect improvement of grain yield in bread wheat. Correlation analysis among grain yield and other traits manifested that traits like flag leaf area $(\mathrm{rp}=0.31)$, days to maturity $(\mathrm{rp}=0.29)$, plant height $(\mathrm{rp}=0.51)$, fertile tillers plant $^{-1} \quad(\mathrm{r} p=0.31)$, biological yield $(\mathrm{rp}=0.94)$ and harvest index $(\mathrm{rp}=0.73)$ showed significant contribution towards grains yield (Table 4). These results envisage the use of these traits for yield improvement in wheat. Reddy et al. (2017) pointed out that tillers plant ${ }^{-1}$, grains spike ${ }^{-1}$, test weight, biological yield plant ${ }^{-1}$ and harvest index are important traits, significantly affecting grain yield. Similarly, Zeeshan et al. (2014), Iftikhar et al. (2013) and Ghafoor et al. (2013) also pointed out significant contribution of days to maturity, flag leaf area, plant height, tillers plant $^{-1}$ and biological yield towards grain yield. However, Baranwal et al. (2012) assessed significantly negative association between plant height and grain yield. No correlation between grains spike ${ }^{-1}$ and grain yield and spikelets spike ${ }^{-1}$ and grain yield is in line with the results of Khan et al. (2013) and Ajmal et al. (2009), respectively. Contrary to our results, Moustafa and Omer (2014) assessed correlation in some derived segregating wheat populations and pointed out significant phenotypic correlation of grain yield with spikelets and grains spike ${ }^{-1}$. Similarly, Kashif and Khaliq (2004) also pointed out notable contribution of spike length and spikelets and grains spike ${ }^{-1}$ towards grain yield. 
Table 2: Mean values for various traits of 24 of wheat genotypes.

\begin{tabular}{|c|c|c|c|c|c|c|c|c|c|c|c|c|}
\hline Genotypes & DH & FLA & DM & PH & FT & BY & SL & SSP & GSP & HGW & GY & HI \\
\hline \multicolumn{13}{|l|}{ Parents } \\
\hline Janbaz & 125.33 & 25.81 & 169.67 & 100.57 & 9.30 & 59.03 & 12.90 & 21.97 & 72.47 & 4.22 & 24.81 & 42.07 \\
\hline Siren & 125.67 & 25.93 & 168.67 & 94.66 & 9.07 & 50.76 & 13.03 & 20.73 & 60.77 & 4.38 & 21.66 & 42.73 \\
\hline Fakhr-e-Sarhad & 134.33 & 31.78 & 173.33 & 100.27 & 10.03 & 56.92 & 13.24 & 21.50 & 74.10 & 3.64 & 27.16 & 47.87 \\
\hline Pirsabak-2005 & 130.33 & 36.43 & 173.00 & 108.97 & 10.17 & 58.25 & 12.67 & 18.90 & 64.10 & 4.71 & 26.06 & 44.98 \\
\hline AUP-5008 & 132.33 & 26.60 & 169.67 & 94.54 & 10.23 & 37.87 & 12.90 & 20.03 & 68.13 & 3.98 & 13.80 & 36.23 \\
\hline Tatara & 123.67 & 28.99 & 169.67 & 100.68 & 9.60 & 46.34 & 10.96 & 18.00 & 63.43 & 4.51 & 18.78 & 40.69 \\
\hline Saleem-2K & 125.00 & 23.74 & 170.67 & 90.71 & 8.13 & 45.01 & 12.64 & 19.77 & 71.70 & 3.94 & 18.03 & 40.42 \\
\hline Barsat & 124.33 & 27.92 & 169.33 & 98.40 & 8.83 & 41.62 & 13.30 & 19.57 & 63.73 & 4.69 & 17.64 & 42.59 \\
\hline Mean (Parents) & 127.63 & 28.40 & 170.50 & 98.60 & 9.42 & 49.47 & 12.70 & 20.06 & 67.30 & 4.26 & 20.99 & 42.20 \\
\hline $\operatorname{LSD}_{(0.05)}$ & 3.54 & 3.63 & 2.95 & 5.72 & 1.43 & 4.04 & 1.19 & 1.24 & 2.81 & 0.27 & 2.07 & 3.46 \\
\hline \multicolumn{13}{|l|}{$F_{2}$ populations } \\
\hline AUP-5008 / Janbaz & 129.67 & 29.44 & 173.67 & 103.84 & 7.97 & 53.24 & 12.85 & 21.07 & 70.93 & 4.20 & 22.41 & 42.03 \\
\hline Tatara / Janbaz & 122.00 & 30.34 & 169.33 & 98.74 & 7.40 & 46.64 & 13.18 & 20.62 & 70.00 & 4.61 & 20.44 & 43.25 \\
\hline Saleem-2K / Janbaz & 131.00 & 26.28 & 170.67 & 94.78 & 8.13 & 45.98 & 12.61 & 22.47 & 71.33 & 4.59 & 20.24 & 44.07 \\
\hline Barsat / Janbaz & 132.00 & 28.91 & 173.67 & 100.58 & 7.63 & 40.96 & 12.70 & 20.37 & 70.25 & 4.45 & 16.86 & 39.65 \\
\hline AUP-5008 / Siren & 125.67 & 23.52 & 173.67 & 103.86 & 9.77 & 56.95 & 12.26 & 20.52 & 65.72 & 4.19 & 26.09 & 45.47 \\
\hline Tatara / Siren & 131.00 & 29.65 & 172.00 & 102.28 & 7.95 & 53.87 & 12.19 & 19.97 & 66.37 & 4.44 & 22.02 & 40.53 \\
\hline Saleem-2K / Siren & 133.00 & 26.56 & 173.33 & 92.60 & 9.32 & 50.66 & 11.96 & 19.95 & 73.32 & 4.01 & 21.74 & 42.55 \\
\hline Barsat / Siren & 128.00 & 27.54 & 170.67 & 101.34 & 9.55 & 60.93 & 13.52 & 20.55 & 65.63 & 4.72 & 27.93 & 45.39 \\
\hline AUP-5008 / FS & 125.33 & 28.46 & 170.33 & 106.99 & 9.92 & 51.51 & 12.04 & 19.85 & 64.15 & 4.38 & 21.73 & 42.40 \\
\hline Tatara / FS & 124.33 & 26.02 & 170.00 & 101.43 & 8.83 & 46.01 & 11.42 & 19.68 & 65.27 & 4.39 & 19.85 & 43.72 \\
\hline Saleem-2K / FS & 133.33 & 22.79 & 173.00 & 95.94 & 8.60 & 45.21 & 12.05 & 21.67 & 63.82 & 4.16 & 18.18 & 39.63 \\
\hline Barsat / FS & 128.00 & 26.15 & 173.00 & 99.65 & 8.55 & 50.02 & 12.83 & 20.43 & 61.68 & 4.48 & 21.66 & 43.00 \\
\hline AUP-5008 / PS-05 & 130.33 & 28.96 & 171.33 & 107.12 & 9.72 & 57.07 & 11.27 & 19.45 & 72.15 & 4.57 & 24.41 & 42.59 \\
\hline Tatara / PS-05 & 131.33 & 28.63 & 173.33 & 107.35 & 8.92 & 57.56 & 11.69 & 20.53 & 65.40 & 4.85 & 25.65 & 44.62 \\
\hline Saleem-2K / PS-05 & 128.33 & 24.85 & 168.67 & 96.97 & 8.98 & 46.76 & 11.78 & 20.70 & 72.78 & 3.94 & 19.41 & 40.89 \\
\hline Barsat / PS-05 & 127.67 & 27.98 & 169.67 & 98.57 & 8.87 & 48.65 & 12.43 & 20.72 & 78.88 & 4.10 & 21.61 & 43.78 \\
\hline Mean ( $F_{2}$ populations) & 128.81 & 27.25 & 171.65 & 100.75 & 8.76 & 50.75 & 12.30 & 20.53 & 68.61 & 4.38 & 21.89 & 42.72 \\
\hline $\operatorname{LSD}_{(0.05)}$ & 3.37 & 3.45 & 2.81 & 5.45 & 1.36 & 3.84 & 1.13 & 1.18 & 2.68 & 0.25 & 1.97 & 3.29 \\
\hline Mean (Genotypes) & 128.42 & 27.64 & 171.26 & 100.03 & 8.98 & 50.33 & 12.43 & 20.38 & 68.17 & 4.34 & 21.59 & 42.55 \\
\hline $\operatorname{LSD}_{(0.05)}$ & 3.32 & 3.40 & 2.77 & 5.37 & 1.34 & 3.79 & 1.11 & 1.17 & 2.64 & 0.25 & 1.94 & 3.25 \\
\hline
\end{tabular}

LSD $_{(0.05)}$ .77 5.37 $\begin{array}{lll}8.98 & 50.33 & 12.43 \\ 1.34 & 3.79 & 1.11\end{array}$ 1.17 2.64 $1.94 \quad 3.25$

Note: DH- days to $50 \%$ heading, FLA- flag leaf area, DM- days to maturity, PH- plant height, FT- fertile tillers plant ${ }^{-1}$, BY- biological yield plant ${ }^{-1}$, SL- spike length, SSP- spikelets spike ${ }^{-1}$, GSP- grains spike ${ }^{-1}$, HGW-100-grain weight, GY- grain yield plant ${ }^{-1}$ and HI- harvest index. 
Table 3: Heritability and genetic advance for various quantitative traits of $16 \mathrm{~F}_{2}$ populations of wheat.

\begin{tabular}{|c|c|c|c|c|c|c|c|c|c|c|c|c|c|c|c|c|c|c|c|c|}
\hline \multirow[b]{2}{*}{$F_{2}$ Populations } & \multicolumn{2}{|l|}{ FLA } & \multicolumn{2}{|l|}{$\mathbf{P H}$} & \multicolumn{2}{|l|}{ FT } & \multicolumn{2}{|l|}{ BY } & \multicolumn{2}{|l|}{ SL } & \multicolumn{2}{|l|}{ SSP } & \multicolumn{2}{|l|}{ GSP } & \multicolumn{2}{|c|}{ HGW } & \multicolumn{2}{|l|}{ GY } & \multicolumn{2}{|l|}{ HI } \\
\hline & $h^{2}$ & GA & $h^{2}$ & GA & $h^{2}$ & GA & $h^{2}$ & GA & $h^{2}$ & GA & $h^{2}$ & GA & $h^{2}$ & GA & $h^{2}$ & GA & $h^{2}$ & GA & $h^{2}$ & GA \\
\hline AUP-5008 / Janbaz & 0.56 & 5.49 & 0.25 & 2.06 & 0.27 & 0.87 & 0.72 & 18.48 & 0.36 & 0.55 & 0.50 & 1.13 & 0.68 & 11.85 & 0.30 & 0.20 & 0.69 & 9.21 & 0.48 & 5.92 \\
\hline Tatara / Janbaz & 0.89 & 9.74 & 0.43 & 4.16 & 0.65 & 2.15 & 0.89 & 18.18 & 0.56 & 0.89 & 0.65 & 1.49 & 0.66 & 5.98 & .48 & 0.33 & .88 & 0.43 & 0.70 & 7.14 \\
\hline Saleem-2K / Janbaz & 0.92 & 11.48 & 0.62 & 7.30 & 0.82 & 3.69 & 0.93 & 25.26 & 0.49 & 0.77 & 0.54 & 1.38 & 0.85 & 11.75 & .66 & .74 & .91 & 11.91 & 0.73 & 8.23 \\
\hline Barsat / Janbaz & 0.78 & 7.97 & 0.66 & 6.46 & 0.60 & 2.20 & 0.88 & 21.46 & 0.57 & 0.87 & 0.66 & 1.46 & 0.65 & 6.30 & 0.52 & 0.35 & 0.90 & 11.34 & 0.71 & 8.13 \\
\hline / Siren & 0.78 & 6.9 & 058 & 5.03 & 71 & 3.02 & 0.91 & 22.63 & 047 & 062 & 0.76 & 187 & 0.83 & .20 & 63 & 0.50 & 0.92 & 12.98 & 0.68 & 7.39 \\
\hline Tatara / Siren & 0.86 & 9.71 & 0.87 & 14.99 & 0.67 & 2.50 & 0.91 & 24.64 & 0.61 & 0.91 & 0.83 & 2.55 & 0.88 & 14.83 & 0.67 & 0.55 & 0.91 & 12.60 & 0.78 & 9.47 \\
\hline Saleem-2K / Si & 0.85 & 8.71 & 0.60 & 5.70 & 0.10 & 5.J5 & 0.09 & 24.22 & 0.56 & 0.81 & 0.55 & 1.34 & 0.83 & 11.78 & 0.22 & 0.15 & 0.92 & 12.70 & 0.71 & 7.93 \\
\hline Barsat / Siren & 0.81 & 8.74 & 0.66 & 6.44 & 0.64 & 2.45 & 0.89 & 21.64 & 0.55 & 0.82 & 0.77 & 2.07 & 0.84 & 12.00 & 0.52 & 0.35 & 0.91 & 11.93 & 0.60 & 5.85 \\
\hline AUP-5008 / F.S & 0.84 & 9.25 & 0.71 & 7.09 & 0.78 & 3.55 & 0.94 & 26.38 & 0.50 & 0.73 & 0.59 & 1.21 & 0.85 & & 0.38 & 0.25 & 0.90 & 55 & 0.65 & 6.71 \\
\hline Tatara / F.S & 0.89 & 12.16 & 0.61 & 5.83 & 0.78 & 3.26 & 0.87 & 18.59 & 0.54 & 0.81 & 0.61 & 1.31 & 0.79 & 9.32 & 0.39 & 0.24 & 0.85 & 8.96 & 0.82 & 10.86 \\
\hline Saleem-2K / F.S & 0.74 & 6.17 & 0.63 & 6.00 & 0.74 & 2.90 & 0.85 & 18.67 & 0.42 & 0.59 & 0.45 & 1.07 & 0.66 & 6.18 & 0.22 & 0.16 & 0.86 & 2 & 0.70 & 7.45 \\
\hline Barsat / F.S & 0.78 & 8.4 & 0.47 & 3.58 & 0.73 & 2.98 & 0.91 & 22.94 & 0.55 & 0.88 & 0.67 & 1.58 & 0.87 & 12.76 & 0.51 & 0.36 & 0.90 & 11.02 & 0.69 & 7.55 \\
\hline AUP-5008 / PS-05 & 0.83 & 8.8 & 0.87 & 15.59 & 0.77 & 3.53 & 0.95 & 28.64 & 0.61 & 1.04 & 0.74 & 1.90 & 0.87 & 13.25 & 0.44 & 0.28 & 0.92 & 13.48 & 0.57 & 5.48 \\
\hline Tatara / PS-05 & 0.83 & 9.07 & 0.82 & 13.85 & 0.84 & 4.22 & 0.92 & 25.84 & 0.55 & 0.85 & 0.66 & 1.57 & 0.79 & 9.94 & 0.80 & 0.85 & 0.90 & 12.21 & 0.56 & 4.89 \\
\hline Saleem-2K / PS-05 & 0.68 & 5.07 & 0.76 & 10.79 & 0.77 & 3.27 & 0.86 & 19.41 & 0.43 & 0.62 & 0.61 & 1.75 & 0.56 & 4.76 & 0.11 & 0.07 & 0.88 & 10.49 & 0.62 & 6.18 \\
\hline Barsat / PS-05 & 0.81 & 9.25 & 0.57 & 5.71 & 0.77 & 3.54 & 0.91 & 22.82 & 0.32 & 0.43 & 0.66 & 1.58 & 0.83 & 11.17 & 0.40 & 0.24 & 0.90 & 11.82 & 0.72 & 8.49 \\
\hline
\end{tabular}

Note: FLA- flag leaf area, PH- plant height, FT- fertile tillers plant ${ }^{-1}$, SL- spike length, BY- biological yield, SSP- spikelets spike ${ }^{-1}$, GSP- grains spike ${ }^{-1}$,

HGW- 100-grain weight, GY- grain yield plant ${ }^{-1}$ and HI- harvest index. 
Table 4: Correlation coefficients for various quantitative traits with grain yield.

\begin{tabular}{lll}
\hline Traits & Phenotypic correlation $(\boldsymbol{r p})$ & $\boldsymbol{P}$-value \\
\hline Days to heading & 0.08 & 0.506 \\
\hline Flag leaf area & 0.31 & 0.008 \\
\hline Days to maturity & 0.29 & 0.014 \\
\hline Plant height & 0.51 & 0.000 \\
\hline Fertile tillers plant $^{-1}$ & 0.31 & 0.007 \\
\hline Biological yield & 0.94 & 0.000 \\
\hline Spike length & 0.07 & 0.559 \\
\hline Spikelets spike & 0.13 & 0.273 \\
\hline Grains spike & 0.05 & 0.665 \\
\hline 100-grain weight & 0.16 & 0.183 \\
\hline Harvest index & 0.73 & 0.000 \\
\hline
\end{tabular}

\section{CONCLUSIONS AND RECOMMENDATIONS}

1. Significant differences were observed among all the genotypes for all the traits studied, representing sufficient genetic variability for effective selection.

2. Most of the assessed traits witnessed high heritability and genetic advance in most of the $F_{2}$ populations, which suggested that improvement for these traits would be fruitful through selection of these traits.

3. Traits like days to maturity, flag leaf area, plant height, fertile tillers plant ${ }^{-1}$, biological yield and harvest index manifested notable contribution towards grain yield, therefore, may be considered as effective criteria for selection towards improvement of grain yield in wheat.

\section{AUTHORS CONTRIBUTIONS}

This research article is an integral part of Masters Study of the first author T. Iqbal. G. Hassan conceived the idea and formulated the research. $T$. Iqbal performed the experiment and wrote the first draft of the manuscript. G. Hassan made critical corrections in the first draft. I. Hussain helps in data collection and provided technical support. All authors read and approved the final manuscript.

\section{REFRENCES}

Abd El- Mohsen, A.A., R. Samir, A. Hegazy and M.H. Taha. 2012. Genotypic and phenotypic interrelationships among yield and yield components in Egyptian bread wheat genotypes. J. Pl. Breed. Crop Sci. 4(1): 9-16.

Abderrahmane, H., F. Abidine, B. Hamenna and B. Ammar. 2013. Correlation, path analysis and stepwise regression in durum wheat (Triticum durum Desf.) under rainfed conditions. J. Agric. Sustain. 3(2):122-131.
Abinasa, M., A. Ayana and G. Bultosa. 2011. Genetic variability, heritability and trait associations in durum wheat (Triticum turgidum L. var. durum) genotypes. Afr. J. Agric. Res. 6(17): 3972-3979.

Ajmal, S., N. Zakir, M. Yaqoob and Y. Mujahid. 2009. Estimation of genetic parameters and character association in wheat. J. Agric. Biol. Sci. 1(1):15-18.

Ali, I.H and A.O. Abdulla. 2016. Genetic variability, correlation, path analysis and discriminant function of $\mathrm{F}_{2}$ generations population in bread wheat (Triticum aestivum). Jordon J. Agric. Sci. 12(4): 10271039.

Al-Jibouri, H.A., P.A. Miller and H.F. Robinson, 1958. Genotypic and Environmental Variances and Covariances in an Upland Cotton Cross of Interspecific Origin. Agron. J. 50: 633-637.

Allard, R.W. 1960. Principles of Plant Breeding. John Wiley and Sons, New York.

Aremu, C.O. 2012. Exploring statistical tools in measuring genetic diversity for crop improvement. In: Genetic Diversity in Plants. Edited by M. Caliskan (InTech). 340-348.

Azam. S.M., F. Mohammad, I. Ahmad, I.H. Khalil, S.A. Jadoon and A. Nasim. 2013. Divergence in $\mathrm{F}_{3}$ segregating bread wheat populations. Int. J. Agric. App. Sci. 13(03): 16.

Baloch, M.J., E. Baloch, W.A. Jatoi and N.F. Veesar. 2013. Correlations and heritability estimates of yield and yield attributing traits in wheat. Pak. J. Agri. Engg. Vet. Sci. 29 (2): 96105.

Baranwal, D.K., V.K. Mishra, M.K. Vishwakarma, P.S. Yadav and B. Arun. 2012. Studies on genetic variability, correlation and path analysis for yield and yield contributing traits in wheat. Pl. Arch. 12(1): 99-104. 
Dogan, R. 2009. The correlation and path coefficient analysis for yield and some yield components of durum wheat (Triticum turgidum var. durum L.) in west Anatolia conditions. Pak. J. Bot. 41(3): 1081-1089.

Eid, M.H. 2009. Estimation of heritability and genetic advance of yield traits in wheat (Triticum aestivum L.) under drought condition. Int. J. Genet. Mol. Biol. 1(7): 115120.

Federal Bureau of Statistics (FBS). 2014. Agricultural statistics of Pakistan. Govt. of Pakistan. Islamabad.

Firouzian, A., A.S. Khan and Z. Ali. 2003. Genetic variability and inheritance of grain yield and its components in wheat. Pak. J. Agric. Sci. 40: $3-4$

Gelalcha, S and R.R. Hanchinal. 2013. Correlation and path analysis in yield and yield components in spring bread wheat (Triticum aestivum L.) genotypes under irrigated condition in Southern India. African J. Agric. Res. 8(24): 3186-3192.

Ghafoor, G., G. Hassan, I. Ahmad, S.N. Khan and S. Suliman. 2013. Correlation analysis for different parameters of $\mathrm{F}_{2}$ bread wheat population. Pure Appl. Biol. 2(1): 28-31.

Hussain, F., M. Rafiq, Z. Iqbal, J. Iqbal and M.A. Chowdhry. 2013. Estimates of heritability and genetic advance for grain yield and its components in different segregating populations of wheat. J. Agric. Res. 51(4): 349-60.

Ijaz, F., I. Khaliq, M.T. Shahzad and B. Saleem. 2013. Computation of heritability of yield and some morphological traits in $\mathrm{F}_{2}$ populations of spring wheat (Triticum aestivum L). Int. J. Modern Agric. 2(3): 102-107.

Ijaz, U. and Samiullah. 2013. Heritability estimates of physiological and yield components in bread wheat under rainfed condition. Int. J. Mol. Agric. 2(2): 58-63.

Karim, M.D.H. and M.A. Jahan. 2013. Comparative study of yield and yield contributing traits of different genotypes in bread wheat. J. Agric. \& Biol. Sci. 8(2): 147151.

Kashif, M and I. Khaliq. 2004. Heritability, correlation and path coefficient analysis for some metric traits in wheat. Int. J. Agric. Biol. 6(1): 138-142.

Khan, S. A., I. Saleem and Z. Ali. 2003. Heritability of various morphological traits in wheat. Int. J. Agri. Biol. 5(2): 138-140.
Mahmud, I. and H.H. Kramer. 1951. Segregation for yield, height and maturity following a soybean cross. Agron. J. 43: 605-609.

Memon, S.M., B.A. Ansari and M.Z. Balouch. 2005. Estimation of genetic variation for agroeconomic traits in spring wheat (Triticum aestivum L.). Ind. J. Plant Sci. 4:171-175.

Moustafa, E.S.A and S.A. Omar. 2014. Correlation and path coefficient analysis of yield and its components in some derived populations of bread wheat under drought stress conditions. Egypt. J. Plant Breed. 18(4):701-714.

Rashid, J., F. Anwar, Abdullah and I. Khaliq. 2013. Estimation of heritability for some polygenic traits in hexaploid wheat. Int. J. Agri. Crop Sci. 6(8): 458-463

Reddy, A.K., B. Yadav, P.K. Rai and G.M. Lal. 2017. Genotypic performance of $F_{5}$ segregating population of wheat (Triticum aestivum L. Em. Thell.). J. Pharmacogn. Phytochem. 6(5): 1142-1146.

Robinson, H.F., R.E. Comstock and P.H. Harvey. 1949. Genotypic and phenotypic correlations in corn and their implications in selection. Agron. J. 43: 282-287.

Saleem, I., A.S. Khan and Z. Ali. 2003. Estimates of heritability and genetic advance for grain yield traits in Triticum aestivum L. J. Anim. Pl. Sci. 13(1): 52-54.

Saleem. B., A.S. Khan, M.T Shahzad and F. Ijaz. 2016. Estimation of heritability and genetic advance for various metric traits in seven $F_{2}$ populations of bread wheat (Triticum aestivum L.). J. Agric. Sci. 61(1): 1-9.

Shoukat, A.M., A.S. Mahboob, A.A. Bashir and M. Afzal. 2007. Study of genetic parameters in segregating populations of spring wheat. Pak. J. Bot. 39(7): 2407-2413.

Sial, M.A., J. Akhtar, A.A. Mirbahar, K.D. Jamali, N. Ahmed and H. Bux. 2013. genetic studies of some yield contributing traits of $\mathrm{F}_{2}$ segregating generation of bread wheat. Pak. J. Bot. 45(5): 1841-1846.

Sing, R.K. and B.D. Chaudhary. 1985. Biometrical methods in quantitative genetic analysis.

Waqas, M., M. Faheem, A. S. Khan, M. Shehzad and M.A.A. Ansari. 2014. Estimation of heritability and genetic advance for some yield traits in eight $F_{2}$ populations of wheat (Triticum aestivum L). Sci. Lett. 2(2): 43-47.

Zeeshan, M., W. Arshad, M.I. Khan, S. Ali and M. Tariq. 2014. Character association and casual effects of polygenic traits in spring wheat (Triticum aestivum L.). Int. J. Agric. Forestry and Fisheries, 2(1): 16-21. 